\title{
Critical Spatial Practice
}

Jane Rendell

'You can't design art!' a colleague of mine once warned a student of public art. One of the more serious failings of some so-called public art has been to do precisely this, to produce public spaces and objects that provide solutions - answers rather than questions. If there is such a practice as public art, and that in itself is debatable, then I argue that public art should be engaged in the production of restless objects and spaces, ones that provoke us, that refuse to give up their meanings easily but instead demand that we question the world around us.

Public Art is an interdisciplinary practice, one that refuses to settle as simply art or design. If design can be considered a form of practice that is usually conducted in response to a brief or a set of requirements, and if fine art is defined by its independence from such controls, then public art, in drawing on both approaches, can construct a series of differing responses to sites, forming a continuum of practice located between art and design. If designers are expected to provide solutions to problems, albeit creative ones within a given set of parameters, and artists are encouraged to rethink the terms of engagement, then public art practice, by operating in a place between them, is well positioned to address the procedures of both art and architecture.

When art is located outside the gallery, the parameters that define it are called into question and all sorts of new possibilities for thinking about the relationship between art and architecture are opened up. Art has to engage with the kinds of restraints and controls to which only architecture is usually subject. In many public projects, art is expected to take on 'functions' in the way that architecture does, for example to alleviate social problems, comply with health and safety requirements, or be accessible to diverse audiences and groups of users. But in other sites and situations art can adopt more critical functions and works can be positioned in ways that make it possible 
to question the terms of engagement of the projects themselves. This type of public art practice is critically engaged; it works in relation to dominant ideologies yet at the same time questions them and explores the operations of particular disciplinary procedures - art and architecture - while also drawing attention to wider social and political problems; it might then best be called 'critical spatial practice'. ${ }^{1}$

In Michel de Certeau's discussion of spatial practices, he uses the terms strategy and tactic. For de Certeau, strategies seek to create places that conform to abstract models; whereas tactics do not obey the laws of places. ${ }^{2}$ For Henri Lefebvre, spatial practices, along with representations of space and spaces of representation, form a trialectical model where space is produced through three inter-related modes. ${ }^{3}$ For Lefebvre, spatial practices can be understood in terms of perception and representations of space in terms of conception. Lefebvre also makes a careful distinction between representations of space and spaces of representation; the first he sees as operations which involve a systematized set of abstract and dominant codes, the second as the spaces of resistance, where invention and imagination flourish.

It is possible to draw connections between de Certeau's strategies and Lefebvre's representations of space on the one hand, and de Certeau's tactics and Lefebvres' spaces of representation on the other, and suggest a distinction between those practices (strategies) that operate to maintain and reinforce existing social and spatial orders, and those practices (tactics) that seek to critique and question them. I favour such a distinction and call the latter - critical spatial practice - a term which serves to describe both everyday activities and creative practices which seek to resist the dominant social order of global corporate capitalism.

This new term, 'critical spatial practice', draws attention then to the importance of the spatial, but not only the spatial, also the critical. The term 
'theory' is often understood to refer to modes of enquiry in science through either induction, the inference of scientific laws or theories from observational evidence, or deduction, a process of reasoning from the general overarching theory to the particular. Critical theory is a phrase that refers to the work of a group of theorists and philosophers called the Frankfurt School operating in the early twentieth century. The group includes Theodor Adorno, Jurgen Habermas, Max Horkheimer, Herbert Marcuse and Benjamin; and their writings are connected by their interest in the ideas of the philosopher G. W. F. Hegel, the political economist Karl Marx, and the psychoanalyst Sigmund Freud. Taken together, their work could be characterized as a rethinking or development of Marxist ideas in relation to the shifts in society, culture and economy that took place in the early decades of the twentieth century.

Critical theories are forms of knowledge, which as Raymond Guess writes in The Idea of Critical Theory ${ }^{4}$ differ from theories in the natural sciences because they are 'reflective' rather than 'objectifying' - in other words they take into account their own procedures and methods. Critical theories aim neither to prove a hypothesis nor prescribe a particular methodology or solution to a problem; instead, in a myriad of differing ways critical theorists offer self-reflective modes of thought that seek to change the world, or at least the world in which the inequalities of market capitalism, as well as patriarchal and colonial (or post-colonial) interests, continue to dominate.

I extend the term 'critical theory' to include the work of later theorists -poststructuralists, postcolonialists, feminists and others - whose thinking is also self critical and desirous of social change. For me, this kind of theoretical work provides a chance not only to reflect on existing conditions, but also to imagine something different - to transform rather than describe. But more importantly, I argue it is possible to extend the 'critical' as defined through critical theory into practice, to include critical practices - those practices that involve social critique, self-reflection and social change. ${ }^{5}$ 
In the last twenty years or so a number of academic disciplines - geography, anthropology, cultural studies, history, art and architectural theory, to name but a few - have been drawn into debates on 'the city'. Such discussions on the urban condition have produced an interdisciplinary terrain of 'spatial theory' that has reformulated the ways in which space is understood and practised. ${ }^{6}$ My hope is that the work of artists critically engaging with sites outside the gallery can help develop an equally influential terrain of spatial understanding through critical practice, as well as critique through spatial practice. As Roland Barthes reminds us 'to criticize means to call into crisis', an undertaking which our current dire situation as one combining peak oil, global food crisis, climate change and military intervention most desperately needs to generate awareness and the need for action.

Biography

Jane Rendell BA (Hons), Dip Arch, MSc, PhD, is Professor of Architecture and Art and Director of Architectural Research at the Bartlett, UCL. An architectural designer and historian, art critic and writer, her work has explored various interdisciplinary intersections: feminist theory and architectural history, fine art and architectural design, autobiographical writing and criticism. She is author of Site-Writing: The Architecture of Art Criticism (forthcoming 2009), Art and Architecture (2006), The Pursuit of Pleasure (2002) and co-editor of Pattern (2007), Critical Architecture (2007), Spatial Imagination (2005), The Unknown City (2001), Intersections (2000), Gender Space Architecture (1999) and Strangely Familiar (1995).

\footnotetext{
${ }^{1}$ For a full discussion of critical spatial practice in art and architecture see Jane Rendell, Art and Architecture: A Place Between (London: I. B. Tauris, 2006).

2 See Michael de Certeau, The Practice of Everyday Life (Berkeley: University of California Press, 1988) p. 29.

3 See Henri Lefebvre, The Production of Space (Oxford: Basil Blackwell, 1991).
} 
${ }^{4}$ Raymond Geuss, The Idea of Critical Theory: Habermas and the Frankfurt School (Cambridge: Cambridge University Press, 1981) p. 2.

${ }^{5}$ For various positions around the possibility of critical work in architecture see for example Jane Rendell, Jonathan Hill, Murray Fraser and Mark Dorrian (eds) Critical Architecture (London: Routledge, 2007).

${ }^{6}$ See for example Mike Crang and Nigel Thrift (eds) Thinking Space (London: Routledge, 2000).

${ }^{7}$ Roland Barthes, 'Writers, Intellectuals, Teachers' [1971] A Roland Barthes Reader, edited with an introduction by Susan Sontag (London: Vintage, 1982) pp. 378-403, p. 379. 